\title{
タンパク質・アミノ酸栄養と放射線障害について (II ) \\ Effect of Protein and Amino acid Nutrition on \\ Radiation Damage in Mice (II)
}

\author{
被曝マウスの造血臓器への $59 \mathrm{Fe}$ 取り込みに対するタンパク質・ \\ アミノ酸栄養の影響について \\ Effect of Protein and Amino acid Nutrition on ${ }^{59} \mathrm{Fe}$ - incorporation \\ into Haematopoetic Organs of Irradiated Mice.
}

（昭 和 44 年 2 月 6 日受 理）

$\begin{array}{cc}\text { 中田 } \\ \text { (Seiei } & \text { Tanaka) }\end{array}$ 英*

The preceding papers revealed that the mortality of a single dose of whole body $\gamma$-irradiated mice was greately reduced by the supplement of protein in diets before and after irradiation. In the present paper, the effect of dietary protein reinforcement after $\gamma$-irradiation on the incorporation of ${ }^{59} \mathrm{Fe}$ into mice blood was reported.

From the results of the experiments, it was shown that the ${ }^{59} \mathrm{Fe}$ incorporation into blood was influenced by the dietary protein nutrition before and after irradiation, and that the importance of protein nutrition in the recovery stage from haematopoetic radiation damage. This findings were in quite accordance with the results of the mortality experiments reported previously.

緒言

前報において著者は死亡率を指標として ddN マウス を用いてコバルト60による 線全身照射を行ない, 照射 後タンパク質を補足することによりかなりの死亡事の隇 少をみた。しかし過㮃のタンパク質添加はむしろ悪影響 を及涩した。著者は放射線障害の著しく現われる機能障 害の 1 つである造血機能障害に注目して, ${ }^{59} \mathrm{Fe}$ の造血蔵 器への取り込みを指標としてタンパク質・アミノ酸栄養 と放射線障害について実験を進めた。

さて栄養学的にみると低タンパク質で飼育したラット

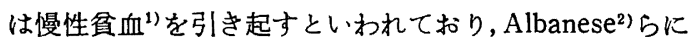
よれば食餌中のアミノ酸でメチオニンとトリプトファン が欠そするといわゆる貧血症状を呈するといっている。

一方放射線障害によって引き起される盆血は一種の再 生不良性蚠血であって骨噵での未熟赤血球の成熟分化の 障害によるものと考えられ, 前述の単なる栄着不良から くる貧血と比べてより複雑なメカニズムによるすのと考 えられる。しかし未熟赤血球の成熟分化にはこれらの血 球の核酸代謝およびタンパク質代謝とが密接な関係にあ って放射線障害による再生不良性貧血からの回復にはフ

\footnotetext{
* 都立アイソトープ研
}

ミノ酸・タンパク質栄養が影響を及ばすであろうことは 想像に難くない。

${ }^{59} \mathrm{Fe}$ の取り込みによる鉄代謝の研究は古くは Hennesy $^{3)}$ らや Belcher ${ }^{4)}$ らの仕事から始まり, 最近迄数多 くの報告がなされている。さて静脈内に投与された ${ }^{50} \mathrm{Fe}$ は大部分24時間以内に血漿中から消失して各荿器, 特に 骨䯣の不安定プールの中に入り, 次いで成熟過程の赤芽 球中でへモグロビン合成に用いられ，成熟赤血球として 循環血液内に現われてくる。末梢血液中の ${ }^{59} \mathrm{Fe}$ は注射 後漸次增加し 5 日ないし10日でプラトーに達する。 ${ }^{30} \mathrm{Fe}$ はまた他の臓器すなわち肝臓, 脾蔵にも分布する。

In vitro の実験では哺乳類の成熟赤血球は ${ }^{59} \mathrm{Fe}$ をそ の中に取り込まない。網状赤血球より若い未熟赤血球の みが ${ }^{59} \mathrm{Fe}$ をその中に取り込むことができる。すなわち ${ }^{59} \mathrm{Fe}$ の取り込みは赤血球の成熟滵接な関係があり, 赤血球がより未熟であればあるほどより多く ${ }^{59} \mathrm{Fe}$ を取 り込むといわれている。

骨䯣機能が障害されて赤血球の成㪟分化が円滑に進行 しないと ${ }^{59} \mathrm{Fe}$ の未熟赤血球への取り込みる阻害され ${ }^{59} \mathrm{Fe}$ は肝臓, 脾䁍など骨䯣以外の臟器に取り込まれる。 このように ${ }^{59} \mathrm{Fe}$ の骨髄の未熟赤血球への取り込みは 
骨盏の造血機能を表わす有力な指標であり，実験的には ${ }^{39} \mathrm{Fe}$ を流血中に注射して一定時間後の流血中の赤血球 の ${ }^{59} \mathrm{Fe}$ の放射能を測り，これを基準としている。 著者はこの方法によって放射線の骨䯑機能に対する障 害と前報に述べた死亡率によるう法との比較を先ず行な い両者の間に併行関係があることを確かめた。次いで前 報で間題にした消化管系統の障害を軽减する目的で食餌 タンパク質の 1 部をアミノ酸混合物に置換える実験を行 なった。また前述のよ5に赤血球の成熟分化は核酸代謝 と密接な関係にあり，プリン塩基でありエネルギー代謝 で重要なATP とも関連のあるイノシンについて食慨に 添加して骨髄機能の回復に効果があるか否かについて検 討した。

\section{実験}

\section{1）材料拈よび方法}

動物は ICR 純系雄マウス（ただし 1 部の実験は ddN 雄マウスを用いた） 3 週令を購入した。飼料は次に示す 標準タンパク質配合飼料（カゼイン18\%）を基本にして 低タンパク質飼料としてカゼイン $6 \%$ 飼料およびアミ， 酸混合飼料を作慗した。

標準タンパク質配合飼料組成

$\begin{array}{lc}\text { 成分名 } & \text { 百分率 }(\%) \\ \text { ミルクカゼイン } & 18 \\ \text { イースト末 } & 2 \\ \text { オイル混合* } & 6 \\ \text { 塩混合** } & 4 \\ \text { ビタ ミン混合*** } & 1 \\ \text { 白 糖 } & 3 \\ \alpha \text {-デン粉 } & 66 \\ & \text { 計 } 100\end{array}$

なお低タンパク質配合飼料はカゼイン含有量を $6 \%$ にし その差 $12 \%$ $\alpha$-デン粉にて補った。

アミノ酸混合飼料組成（全タンパク質中のアミノ酸組 成\%)リジン8.9,トリプトファン1.6,フェニールアラ =ン4.6, ロイシン7.9, グリシン 2.8 , メチオニン 2.5 , スレオニン 4.9, アルギニン 4.3, イソロイシン 6.4 , ハ リン6.3, ヒスチシシン 2.9 , シスチン 0.4 , チロシン 8.1 , ク゚ルタミン酸28.0, アスパラギン酸10.4, 合計 100.00

* 大豆油 4 , 肝油 1 の混合油

** 塩配合

$\mathrm{CaCO}_{3}$ 29. 29, $\mathrm{CaHPO}_{4} \cdot 2 \mathrm{H}_{2} \mathrm{O} 0.43, \mathrm{KH}_{2} \mathrm{PO}_{4} 34.31$, $\mathrm{NaCl} 25.06, \mathrm{MgSO}_{4} \cdot 7 \mathrm{H}_{2} \mathrm{O} 9.98, \mathrm{Fe}\left(\mathrm{C}_{6} \mathrm{H}_{5} \mathrm{O}_{7}\right) \cdot 6 \mathrm{H}_{2} \mathrm{O}$ $0.623, \mathrm{CuSO}_{4} \cdot 5 \mathrm{H}_{2} \mathrm{O} 0.156, \mathrm{MnSO}_{4} \cdot \mathrm{H}_{2} \mathrm{O} 0.121$, $\mathrm{ZnCl}_{2} 0.02$, KI $0.0005, \quad\left(\mathrm{NH}_{4}\right)_{6} \mathrm{Mo}_{7} \mathrm{O}_{24} \cdot 4 \mathrm{H}_{2} \mathrm{O}$ $0.0025 \cdots \cdots$. 合計 100.00

***ビタミン配合
チアミン塩酸 0.059, リボフラビン 0.059, ニュチン 酸 0.294 , パントテン酸カルシウム 0.235 , ピリドキ シン塩酸塩 0.029 , メナジオン 0.006 , ビオチン 0.001 , 葉酸 0.002 , ビタミン $\mathrm{B}_{12} 0.002$, イノシトー ル 1.176, アスコルビン酸 0.588 , 乳糖 $97.551 \cdots \cdots$. 合計 100.00

飼育は実験によっては多少異なるが，通常は18\%カゼ イン飼料にて 1 週間餌ならしを行ない，次いで低タンパ ク質（カゼイン $6 \%$ 食慨群）にて数週間飼育した。照射 は $\gamma$ 線全身 1 回照射 (Co-60), 総線量 800 レントゲン, 線量率 $150 \mathrm{r} / \mathrm{hr}$ にて行なった。 ${ }^{59} \mathrm{Fe}$ の投与は ${ }^{59} \mathrm{FeCl}_{3}$ の形で, $0.01 \mu \mathrm{c} \sim 0.5 \mu \mathrm{c} / 0.1 \mathrm{ml}$ 生食/マウスを尾静脈 に注射し, 一定時間後の血夜, 肝臓, 脾臓への取り込み をみた。 ${ }^{59} \mathrm{Fe}$ の放射能測定は神戸工業の井戸型シンチレ ーションカウンターにて行なった。

\section{結果および考察}

\section{[1] ${ }^{59} \mathrm{Fe}$ 投与基碟実験}

\section{1) 担体鉄の影響}

購入される ${ }^{59} \mathrm{Fe}$ の比放射能はそのロットにより異な りははなはだしい時には 1 桁も異なる。そこで先ず担体 鉄濃度の ${ }^{59} \mathrm{Fe}$ の血液, 肝臓への取り込みに対する影響 をみることにした。すなわち ICR マウス各群 10匹をオ リエンタル固型飼料にて飼育し, $0.1 \mu \mathrm{c}$ の ${ }^{59} \mathrm{FeCl}_{3} 0.1$ $\mathrm{ml}$ 中の鉄溇度を $0.01 \mu \mathrm{g}$ から $5.0 \mu \mathrm{g}$ 迄いろいろかえ て調彆し,この溶液を尾静脈に注射し，5 日後の ${ }^{59} \mathrm{Fe}$ の 取り込みをみた。結果を表 1 に示す。

表 1 の結果から担体の鉄が增加すると血液への ${ }^{59} \mathrm{Fe}$ の取り込みは减少し, 肝蔵への取り込みが增加する傾向 がみられた。それぞれ ${ }^{59} \mathrm{Fe}$ の取り込みと鉄濃度との間 に直線的な関倸は見られなかったが，血液と肝蔵への ${ }^{59} \mathrm{Fe}$ の取り込みの和は鉄濃度と関係なくほほ一定の值 を示した。

なお注射した放射性鉄の血清中での消長に関しては, 別の実験により静注した ${ }^{59} \mathrm{Fe}$ は12時間で 97〜99\%以上 血清から消失し，24時間以上経過すれば無視し得る程度 の放射能しか存在しないことを確かめた。

2) ${ }^{59} \mathrm{Fe}$ の造血臓器への取り込みに対する $\gamma$ 線照射の

\section{影響}

前報に扰いて死亡率をみる 実験の照射線量として， 1,000 レントゲンを選んだが, ${ }^{50} \mathrm{Fe}$ の血液, 肝蔵への取 り込みについても照射線量の対応性をみた。すなわち ICRマウス各群（10匹）につき型通りカゼイン $18 \%$ 食慨 で1週間慨ならしを行なった後，カゼイン $6 \%$ 食餌にて 2 週間飼育した。 $r$ 線照射は 100 レントゲンから 1,000 
表 1 鉄（担体鉄）濃度の ${ }^{59} \mathrm{FeCl}_{3}$ の血液, 肝臟への取り込みに対する影響

\begin{tabular}{c|r|r|r|r|r}
\hline 鉄 䟴 度 & 体 $\begin{array}{r}\text { 重 (平均) } \\
\mathrm{g}\end{array}$ & $\begin{array}{r}\text { 血液への取り込み } \\
(\%)\end{array}$ & $\begin{array}{r}\text { 肝への取り込み } \\
(\%)\end{array}$ & $\begin{array}{r}\text { (血液+肝)合計 } \\
(\%)\end{array}$ & 動 物 数 \\
\hline $0.01 \mu \mathrm{g}$ & 23.8 & $33.8( \pm 2.4)$ & $5.9( \pm 0.7)$ & 39.7 & 10 \\
$0.5 \prime \prime$ & 23.2 & $24.6( \pm 1.8)$ & $14.0( \pm 2.1)$ & 38.6 & 10 \\
$1.0 \prime \prime$ & 22.0 & $23.8( \pm 3.1)$ & $13.0( \pm 1.1)$ & 36.8 & 10 \\
$5.0 \prime \prime$ & 25.0 & $20.7( \pm 2.5)$ & $21.3( \pm 3.0)$ & 42.0 & 10 \\
\hline
\end{tabular}

注 取り込みの\%は，マウス1匹当り，全注射放射能に対する全血，全肝の取り込まれた放射能百分率を示し（士） の数値は S. D. を示す。

表 $2{ }^{59} \mathrm{Fe}$ の造血臓器への取込みと $\gamma$ 線照射線量

\begin{tabular}{|c|c|c|c|c|c|}
\hline \multirow{2}{*}{ 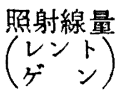 } & \multicolumn{5}{|c|}{${ }^{50} \mathrm{Fe}$ の造血臓器への取込み（\%） } \\
\hline & 液 & 肝 & 蔵 & 脾臟 & 動物数 \\
\hline 0 & $27.5( \pm 2.6)$ & 10.2 & $-12.1)$ & 0.8 & 10 \\
\hline 100 & $25.2( \pm 2.1)$ & 11.4 & $\pm 1.5)$ & 0.7 & 10 \\
\hline 200 & $25.0( \pm 2.0)$ & 10.8 & $( \pm 2.3)$ & 0.7 & 10 \\
\hline 300 & $17.2( \pm 1.2)$ & 17.3 & $( \pm 1.9)$ & 0.8 & 10 \\
\hline 400 & $9.0( \pm 1.5)$ & 26.5 & $\pm 2.6)$ & 0.8 & 10 \\
\hline 600 & $4.4( \pm 0.8)$ & 27.3 & $\pm 5.1)$ & 0.4 & 10 \\
\hline 800 & $3.0( \pm 1.0)$ & 28.0 & $\pm 3.1)$ & 0.3 & 10 \\
\hline 1,000 & $2.1( \pm 0.4)$ & 29.7 & $( \pm 1.9)$ & 0.3 & 10 \\
\hline
\end{tabular}

レントゲン行ない,照射 3 日後に $0.2 \mu \mathrm{c}$ の ${ }^{99} \mathrm{FeCl}_{3}$ を尾 静脈注射し, 注射後 6 日目に血液, 肝臓, 脾臓に取り込 まれた ${ }^{99} \mathrm{Fe}$ の放射能を測定した。結果を表 2 に示す。

表 2 の結果から, 明らかに照射線量が 200 レントゲン を越すと血液への ${ }^{59} \mathrm{Fe}$ の取り込みは急激に低下し,ほほ これに対照的に肝臓への取り込みが上昇した。これは照 射により造血細胞か障害を受けると鉄が供給されてもへ モグロビン合成の方に用いられず，肝臓の貯蔵鉄プール に蓄積されるためと考えられる。著者はこの $6 \%$ \%ガイ ン食慨飼育での ${ }^{56} \mathrm{Fe}$ の血液への取り込みの照射線量に 対する曲線と, 前述の死亡率による実験との関連拉よび 比較的短期間に照射の影響を確実に把握するために比較 的高線量と思われる 800 レントゲン照射（実験の 1 部は 文部研究班研究の目的のため 500 レントゲン照射を行な った）を選び，これを照射線量と定めた。

〔II] ${ }^{59} \mathrm{Fe}$ の血液への取り込みを指標としたタンパク質 栄養の被嚗マウスに対する影響について

1) 低タンパク質食餉にて飼育した被嚗マウスに対する タンパク質の補足効果

マウスを型通り $18 \%$ \%ガイン食慨で慨ならしを行な
い, 低タンパク質食餉（カゼイン $6 \%$ ）にて 2 週間飼育 し， 800 レントゲン 1 回全身照射を行ない，照射後タン パク質量を補足し，18\%カゼイン食餉に民した。 ${ }^{89} \mathrm{Fe} の$ 投与は照射 3 日後に行ない, ${ }^{59} \mathrm{Fe}$ の放射能の測定は注 射後 7 日の血液への取り込み量をみた。結果を表 3 に示 す。

表 $3 r$ 線照射と ${ }^{59} \mathrm{Fe}$ の血液への取り込みに対するタ ンパク質栄養の影響

\begin{tabular}{|c|c|c|c|c|}
\hline \multirow{2}{*}{$\begin{array}{c}\text { 食 } \\
\text { 照射前 }\end{array}$} & \multirow{2}{*}{$\begin{array}{c}\text { 慨 群 } \\
\text { 照射後 }\end{array}$} & \multirow{2}{*}{ 照射 } & \multicolumn{2}{|c|}{$\begin{array}{l}{ }^{59} \mathrm{Fe} \\
\text { 込み血液への取 } \\
(\%)\end{array}$} \\
\hline & & & & 動物数 \\
\hline $\begin{array}{l}6 \% \text { \% } \\
\text { イン食 }\end{array}$ & $\begin{array}{l}\text { 18\%カゼ } \\
\text { イソ食 }\end{array}$ & - & $34.0( \pm 2.4)$ & 15 \\
\hline 11 & $\begin{array}{l}\text { 6\%カゼ } \\
\text { イン食 }\end{array}$ & + & $7.9( \pm 1.3)$ & 10 \\
\hline "I & $\begin{array}{l}\text { 18\%カゼ } \\
\text { イン食 }\end{array}$ & + & $17.0( \pm 2.1)$ & 10 \\
\hline
\end{tabular}

表 3 の結果より照射後タンパク質を低タンパクから標 準タンパクに戻すことにより，すなわち照射後タンパク 質を補足することにより照射により低下した ${ }^{59} \mathrm{Fe}$ の血 液への取り込みの回復がみられた。このことは既述の死 亡率実験の結果と一致し, 死亡率実験と ${ }^{59} \mathrm{Fe}$ の取り込 み実験との平行性を示した。

2 ）低タンパク質飼育被嚗マウスに対するアミノ酸混合 物の添加効果

1）と同様マウスを低タンパク質食餌(カゼイン 6\%) で飼育し, 型通り照射を行ない, 照射後つミノ酸混合物 の添加とタンパク質を全部フミノ酸混合物に直き換えた 影響について ${ }^{59} \mathrm{Fe}$ の血液への取り込みについて検討し た。結果を表 4 に示す。

表 4 の結果より $6 \%$ カゼイン食にアミノ酸混合物を添 加した群拉よびタンパク質を全部フミノ酸混合物に看き 换光た群については ${ }^{58} \mathrm{Fe}$ の血液への取り込みは6\%力 ゼイン食で照射前後を通して飼有した群に比へて確かに 高い值を示した。しかし，いずれもカゼイン $18 \%$ 群すな 
表 4 被曝マウスの ${ }^{50} \mathrm{Fe}$ の血液への取り込みに対する アミノ酸栄養の影䧼

\begin{tabular}{|c|c|c|c|c|}
\hline \multirow{2}{*}{$\begin{array}{c}\text { 食 } \\
{ }^{n} \text { 照射前 }\end{array}$} & \multirow{2}{*}{$\begin{array}{l}\text { 群 } \\
\text { 照射後 }\end{array}$} & \multirow{2}{*}{ 照射 } & \multicolumn{2}{|c|}{$\begin{array}{l}{ }^{50} \mathrm{Fe} \text { の血液への取り } \\
\text { 込み } \\
\end{array}$} \\
\hline & & & & 動物数 \\
\hline $\begin{array}{l}6 \% \text { \%ガ } \\
\text { イン食 }\end{array}$ & $\begin{array}{l}6 \% \text { \%ガ } \\
\text { イン食 }\end{array}$ & + & $7.9( \pm 1.3)$ & 10 \\
\hline "l & $\begin{array}{l}\text { 18\%カゼ } \\
\text { イン食 }\end{array}$ & + & $17.0( \pm 2.1)$ & 10 \\
\hline$\prime \prime$ & $\begin{array}{l}\text { イン食+ } \\
12 \mathrm{AA}^{*}\end{array}$ & + & $10.4( \pm 1.6)$ & $\begin{array}{l}10 \\
10\end{array}$ \\
\hline$\prime \prime$ & $18 \mathrm{AA}^{* *}$ & + & $10.8( \pm 1.7)$ & 10 \\
\hline
\end{tabular}
* $12 \%$ カゼイン相当のアミノ酸混合物
** $18 \%$

わらタンパク質で飼育した群に比べて低い值を示した。 このことは単に腸管からの吸収の問題では説明がつかず 恐らく個々のアミノ酸の吸収率の差違の問題, 食欲に伴 5 食事摄取量の多少の問題なども原因していると考えら れる。

3）イノシンの投与効果 (1)

粕論にて述べた理由で，低タンパク質飼育マウスに $\gamma$ 線照射後イノシンの経口投与実験を試みた。先ず型通り
18\%カゼイン食で慨ならしを行ない，6\%カゼイン食で 6 週間飼育した。次いで 800 レントゲン $\gamma$ 線全身 1 回照 射を行ない, 照射 2 日後に ${ }^{50} \mathrm{Fe}$ を尾静脈に注射し，注 射 4 日後の血液への ${ }^{59} \mathrm{Fe}$ の取り込みをみた。結果を表 5 に示す。

表 5 の結果より ${ }^{59} \mathrm{Fe}$ の血液への取り込みの増加に対 するイノシンの添加効果はイノシン $0.2 \%$ 添加群にみら れたが，0.4\%，0.8\%添加群ではかえって負の效果がみ られた。

4) イノシンの投与効果 (2)

次に $18 \%$ ガイン飼育マウスについて 500 レントゲン 照射後直ちに18\%カゼイン食にイノシンを添加した食䬲 に切換えた実験を行なった。照射と ${ }^{58} \mathrm{Fe}$ の投与は前実 験に準じたが，血液，肝缄への ${ }^{50} \mathrm{Fe}$ の取り込みは注射 6 日後と 15 日後の值を測定した。また照射24時間前にイ ノシンの水溶液を $1 \mathrm{ml}$, 腹腔注射したものについても同 样に ${ }^{58} \mathrm{Fe}$ の取り込み実験を行なった。結果を表 6 に示 †。

表 6 の結果より $18 \%$ ゼイン食餌に照射後イノシンを 添加した実験では，経口投与，腹腔注射ともにその添加 効果は著明にあらわれず，投与量に関しても一定の傾向

表 5 イノシ: の添加実験 (1)

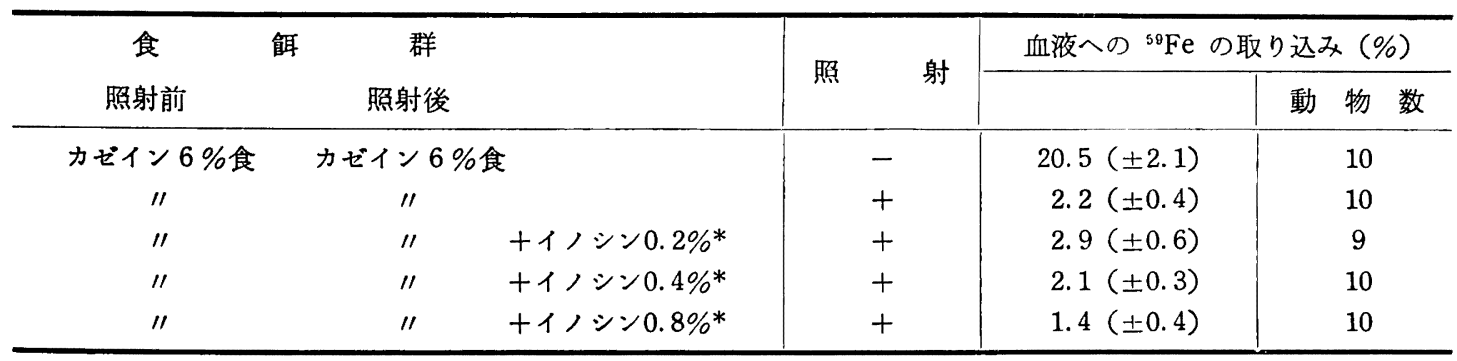

*食餌中のイノシンの百分率

表 6 イノシンの添加実験（2）

\begin{tabular}{|c|c|c|c|c|c|c|c|c|c|}
\hline & 䬲 & 群 & & & & 血液への ${ }^{59} \mathrm{Fe}$ & の取り込み(\%) & 肝缄への ${ }^{59} \mathrm{Fe}$ & の取り込み(\%) \\
\hline 照射前 & & 射後 & & & & 6 日 & 15日 & 6 日 & 15日 \\
\hline $\begin{array}{l}\text { カゼイン } \\
\text { 18\%食 }\end{array}$ & $\begin{array}{l}\text { カゼイン } \\
18 \% \text { 食 }\end{array}$ & & & & + & $4.9( \pm 0.3)$ & $9.8( \pm 0.9)$ & $17.3( \pm 1.5)$ & $15.1( \pm 1.1)$ \\
\hline$" 1$ & "I & +1 & ンン $0.05 \%$ & $*$ & + & $3.5( \pm 0.1)$ & $7.4( \pm 1.3)$ & $16.7( \pm 2.3)$ & $15.2( \pm 1.6)$ \\
\hline$\prime \prime$ & $\prime \prime$ & + & $0.1 \%$ & & + & $5.7( \pm 0.6)$ & $7.3( \pm 0.7)$ & $15.0( \pm 1.6)$ & $14.8( \pm 0.7)$ \\
\hline "l & $\prime \prime$ & + & $0.2 \%$ & & + & $4.7(\dashv-1.1)$ & $7.5( \pm 1.0)$ & $14.9( \pm 2.3)$ & $12.3( \pm 2.0)$ \\
\hline "I & $\prime \prime$ & + & $0.4 \%$ & & + & $3.5( \pm 0.2)$ & $7.8( \pm 1.0)$ & $15.6( \pm 1.1)$ & $14.1( \pm 1.3)$ \\
\hline$\prime \prime$ & $\prime \prime$ & + & $0.001 \mathrm{mg}$ & $* *$ & + & $4.7( \pm 0.4)$ & $8.6( \pm 0.2)$ & $13.7( \pm 2.1)$ & $16.0( \pm 0.9)$ \\
\hline "I & $\prime \prime$ & + & $0.01 \mathrm{mg}$ & & + & $4.1( \pm 0.4)$ & $7.2( \pm 1.3)$ & $15.1( \pm 1.0)$ & $17.0( \pm 1.9)$ \\
\hline$\prime \prime$ & $\prime \prime$ & + & $0.1 \mathrm{mg}$ & & + & $5.1( \pm 0.5)$ & $10.2( \pm 0.6)$ & $17.5( \pm 0.7)$ & $16.8( \pm 3.0)$ \\
\hline$\prime \prime$ & $\prime \prime$ & + & $1.0 \mathrm{mg}$ & & + & $4.4( \pm 0.6)$ & $9.8( \pm 1.2)$ & $20.0( \pm 2.3)$ & $15.7( \pm 2.7)$ \\
\hline
\end{tabular}


を見い出せなかった。

以上 $2 つ$ ノシン添加実験から，十分な栄養状態で はイノシン添加の影響はあらわれないが，タンパク質が 欠乏しているような不良栄盖状態ではその添加の効果が 幾分あらわれるものと思われる。

4) 放射線障害回復期に批林ンパク質栄養の影響

ICR マウスを型通り餌ならしを行なった後, カゼイン $6 \%$ 食慨またはカゼイン $18 \%$ 食餌で 2 週間飼育し， 500 レントゲン（回復に対する食餌の影響をみるため照射線 量を下げた）照射し， ${ }^{59} \mathrm{Fe}$ を照射後経時的に静注し，注 射24時間後の ${ }^{\mathrm{B}} \mathrm{Fe}$ の血液への取り込みをみた。結果を 図 1 に示す。

因 1

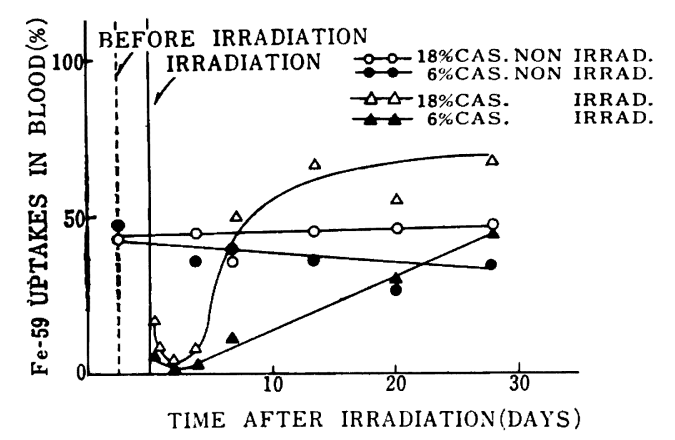

因 1 より明らかにカゼイン $6 \%$ 飼育マウスは照射後も 引きつづき同飼料にて飼育した場合, ${ }^{59} \mathrm{Fe}$ の血液への取 り込みの回復は遅く、これに反してカゼイン18\%飼育、 ウスは照射後 6 日ないし8 日頃から急激に ${ }^{59} \mathrm{Fe}$ の血液 への取り込みの上昇を示した。この結果は前報にて既に 報告した死亡率による実験結果と一致し, 照射後のタン パク質栄盖が放射線障害の回復に重要な意義を持ってい ることを示している。なおカゼイン $18 \%$ の照射群が同飼 料の非照射群より高い取り込み值を示したのは, ${ }^{59} \mathrm{Fe} の$ 取り込み値が注射後24時間の值であるため, 照射後造血 機能が盛んに回復して来たとすれば単位時間当りの回復 能は当然非照射群より高まることから十分理解できる。

結論

${ }^{59} \mathrm{Fe}$ の血液への取り込みを指標として造血機能を注目
して放射線影響とタンパク質栄盖との関係について実驗 を行なってきたが，前報の死亡率による実験の結果とは ほ平行性がみられる結果を得た。すなわち照射後低タン パク質飼育を標準タンパク質飼育に戻すことにより造血 機能の回復効果がみられた。

次にタンパク質を一部アミノ酸混合で置き換えた実験 では,アミノ酸による置換は放射線障害の造血機能に回 復効果を幾分示すがタンパク質そのるのに比べて良い結 果を示さなかった。またイノシンの添加効果に関しても 明確な結果が得られなかった。

またこの ${ }^{59} \mathrm{Fe}$ の取り込みによる方法を用いてタンパ ク質栄盖の放射線障害の回復期における造血機能を経時 的にみた実験では，照射後 1 週間ぐらいから骨㖪機能の 回復がみられ, その回復にタンパク質栄養が大いに役立 っていると思われる結果が得られた。

このよ5に ${ }^{50} \mathrm{Fe}$ の血液への取り込みによる造血機能 の放射線障害時およびその回復期における動向について タンパク質・アミノ酸栄養の量的な影響について追及し てきたか，次にタンパク質の質的な問題すなわちアミノ 酸構成の影響について必須アミノ酸に注目して実験を進 めたいと思う。

本実験に際し常にご毀篤なるご指道を睗わった東大・ 吉川春寿教授, 金大 · 米山良昌教授, 九大・办上茂樹教 授および都立アイソトープ研鈴木治部長に深甚なる感謝 の意を捀げるとともに，アミノ酸, 飼料などにつき何か に便宜を計って下さった田辺アミノ酸研究基金および味 の素K.K.に深く感謝する。

\section{文献}

1) Orten, A. U. and Orten, J. M.: J. Nutr. 26, 21 (1943)

2) Albanese, A. A., Holt, L. E. and Brumback Jr. J. E.: J. Biol. Chem., 165, 179 (1946)

3) Hennessy, T. G., and Huff, R. L.: Proc. Soc. Exptl. Biol. Med., 73, 436 (1950)

4) Belcher, E. H., Gilbert, I.G.F. and Lamerton, L. F.: Brit. J. Radiol., 27, 387 (1954)

5) Belcher, E. H., Harris, E. B., and Lamerton, L. F.,: Progress in Radiobiol., p. 303 (1956) 